\title{
The Chairman's Annual Report for the Years 1978-1979 and 1979-1980
}

The Society's annual courses of lectures (thirteenth in 1978-1979 and fourteenth in 1979-1980) comprised the following topics:

\section{8-1979}

22 November 'The evolution of civic heraldry in Byelorussia', Guy Picarda

13 December 'Schools in Byelorussia in the 16th and 17th centuries', Very Revd Alexander Nadson

14 February 'Byelorussian religious periodicals in emigration (19461978)', Rt Revd Česłau Sipovič

14 March 'A survey of Byelorussian architecture from the 12th to the 18th century', Dr Lindsey Hughes

16 May 'Russification and its opponents in modern Byelorussian literature', Professor Arnold McMillin

13 June 'Byelorussian cartography', John Sallnow

1979-1980

13 December 'The place of church-music in the Byelorussian national revival', Guy Picarda

21 February 'Contemporary tendencies in Byelorussian graphic art', Mikoła Paŭłoŭski

13 March 'Byelorussian confraternities in the 16th century',

17 April 'The Byelorussian suffraganate of the Vilna diocese 1639-1774', Rt Revd Cesłau Sipovič

8 May 'The Hondius Radzivil map (1633) and its place in

Byelorussian cartography', John Sallnow

5 June 'Conternporary Byelorussian writers in Poland', Dr Shirin Akiner

It was especially gratifying to see two new lecturers, John Sallnow of Plymouth Polytechnic and Mikoła Paŭłoŭski, formerly a member of the BSSR Artists' Union and now permanently resident in Paris. Thanks are once again due to the Librarian of the Francis Skaryna Library for allowing the Society to use a room for its lectures and, more pertinently, for unstintingly providing food and drink after the lectures.

The Society is indebted to the Byelorussian Charitable Trust for its continuing financial support. The income and expenditure account 
as on 31 March 80 showed a deficit of $£ 18$, with income at $£ 2,005$ and expenditure at $£ 2,023$. The heaviest single item of expenditure was for the publication of the most recent issue of the Journal of Byelorussian Studies. Members of the Society will of course be eager to see the Journal continue to play its vital role of extending our knowledge of Byelorussia, in spite of the rising costs of paper and printing.

In concluding I should like to express my thanks to the members of the Council, to the Editorial Board of the Journa!, especially Peter Mayo and to all our lecturers and hosts for helping us to continue our activities so successfully.

JOHN JOLLIFFE

Chairman

22 February 1981 